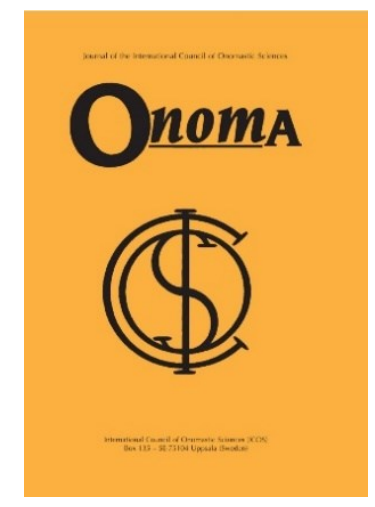

Onoma 54

Journal of the International Council of Onomastic

Sciences

ISSN: 0078-463X; e-ISSN: 1783-1644

Journal homepage: https://onomajournal.org/

\title{
Comparative research of Czech and Finnish place names: Possible problems related to classification, terminology and other differences
}

DOI: $10.34158 /$ ONOMA.54/2019/3

\section{Soňa Wojnarová}

Czech Language Institute of the Czech Academy of Sciences

Valentinská 91/1

11646 Praha 1

Czech Republic

s.wojnarova@ujc.cas.cz

To cite this article: Wojnarová, Soňa. 2019. Comparative research of Czech and Finnish place names: Possible problems related to classification, terminology and other differences. Onoma 54, 39-52. DOI:

10.34158/ONOMA.54/2019/3

To link to this article: https://doi.org/10.34158/ONOMA.54/2019/3

\section{(C) Onoma and the author.}

Comparative research of Czech and Finnish place names: Possible problems related to classification, terminology and other differences

Abstract: This paper deals with colour terms in place names of two different languages and focuses on the issues which might arise in such research. In the case of Czech and Finnish place names, the differences consist primarily in the language systems and in the way words (and names) are formed, and also in the landscape types and the way they are perceived (e.g. in Czech swamps are ranked as water names, whereas in Finnish as terrain names). These differences do not hinder comparative research of colour terms and place names, which are both universal and present in all languages, however, they are reflected in the terminology and classification of both languages and they should be dealt with as long as the description of the material is to be consistent and clear. This can be solved by applying a classification and terminology based on the specific research 
material and on the features common to both languages (in this case, to the level of individual landscape features, such as forest, field, lake).

Keywords: Place names, colour terms, Czech, Finnish, classification, terminology.

\section{Recherche comparative de toponymes tchèques et finnois : Problèmes liés à la classification, à la terminologie et à d'autres différences}

Résumé : Cet article traite de la comparaison des noms de couleur pour les toponymes dans deux langues différentes et se concentre sur les problèmes pouvant survenir dans le cadre d'une telle recherche. Dans le cas des toponymes tchèques et finnois, les différences se situent principalement dans les systèmes linguistiques différents (les mots ainsi que les noms sont formés différemment dans les deux langues) ainsi que dans les types de paysage et leur conception (par exemple, les marécages sont classées parmi les hydronymes en tchèque, mais ils sont classés parmi les oronymes en finnois). Ces différences n'empêchent pas la recherche comparative sur les noms de couleur et les toponymes, qui peuvent être considérés comme universels et présents dans chaque langue, mais elles sont reflétées dans la terminologie et la classification des toponymes dans les deux langues et doivent donc être abordées en priorité pour pouvoir décrire le matériel de manière uniforme. Ce problème peut être résolu en créant une classification spécifique à la recherche, basée directement sur le matériel de recherche et sur ce qui lui est commun (dans ce cas, les différents types d'objets dans le paysage, par exemple une forêt, un champ, un lac).

Mots-clés : Toponymes, noms de couleur, tchèque, finnois, classification, terminologie.

\section{Die vergleichende Forschung über Tschechische und Finnische Flurnamen: Probleme, die im Zusammenhang mit Klassifikation, Terminologie und anderen Unterschieden entstehenden können}

Zusammenfassung: In diesem Aufsatz werden die vergleichende Forschung von Farbwörtern in Flurnamen von zwei Sprachgebieten behandelt und die Probleme diskutiert, die aufgrund der Unterschiede zwischen diesen zwei Sprachen und Gebieten während der Forschung entstehen können. Im Falle von Tschechisch und Finnisch bestehen die Unterschiede erstens darin, wie Wörter (und Namen) in beiden Sprachsystemen gebildet werden, und zweitens in den Landschaftstypen und wie diese wahrgenommen werden (z. B. in der tschechischen Namenforschung werden Sümpfe $\mathrm{zu}$ den Hydronymen eingeordnet, aber in der finnischen zu den Oronymen). Solche Unterschiede können nicht an der vergleichenden Forschung von Farben und Namen hindern, weil diese in jeder Sprache anwesend sind und als universal betrachtet werden, sie kommen allerdings in Terminologie und Klassifikation der beiden Sprachen hervor und es ist deshalb notwendig sich mit ihnen zu beschäftigen, so dass die Beschreibung des Forschungsmaterials möglichst klar und einheitlich wäre. Das kann man mit einer Klassifikation und Terminologie lösen, die ganz konkret nach dem Forschungsmaterial aufgrund der gemeinsamen Zügen geschaffen wird (in diesem Falle sind das die individuellen Objekte in der Landschaft, z. B. Wald, Feld, Tümpel).

Schlüsselbegriffe: Flurnamen, Farbwörter, Tschechisch, Finnisch, Klassifikation, Terminologie. 


\title{
Comparative research of Czech and Finnish place names: Possible problems related to classification, terminology and other differences
}

\author{
SOŇA WOJNAROVÁ
}

\section{Introduction}

This paper is an attempt to deal with issues, which are inevitably encountered when comparing two (or more) distinct objects or groups, in this case place names of two different language and classification systems. Comparing two languages can actually bring forward differences and similarities which can be further applied in individual research of the two languages: comparing can enhance the sensitivity of the researcher and help notice those features which otherwise would go unnoticed if only one language were analysed (Kolehmainen et al. 2013: 18). According to Järventausta (2013: 99), the basis of a comparative analysis is the presumption that languages can be compared among each other. She also adds that it is usually a formal or semantic analogy between the two languages on which basis the contrastive analysis is carried out (ibid.: 105).

The comparison of classification approaches was initiated by the need to find a more solid ground and terminology solution when working with the material for my dissertation project which focuses on colour terms in Czech and Finnish place names. ${ }^{1}$ Its aim is to find out what colour terms appear in

The reason for choosing these two languages is simple, one being my mother tongue, the other being a second language I have studied at university, which enables me to use the place name collections in the other language area. The research is being carried out on the material available in the collections of Finnish Name Archive (NA, see references) and the collections of the Department of Onomastics in Czech Language Institute (SPJ, see references). The latter include only the place names from the area of Bohemia, the western half of the Czech Republic. The collection of Silesian and Moravian place names, stored in the Department of Dialectology in Czech Language Institute, is not accessible, only the entries already processed in The dictionary of non-settlement place names in Moravia and Silesia (SPJMS, see references) can be made available. I was permitted to get only to a part of them, specifically to the place names including the basic (underived) forms of the colour terms bily' 'white' and černy' 'black' whose dictionary entries have already been processed. These place names made available can be used for a case study but not for the research of colour terms in place names of the whole Czech language region in general since a great deal of names (all billý and černý derivatives and also names including other colour terms) could not be included. Therefore, when referring to "Czech place names", I mean those from the area of Bohemia, unless stated otherwise. 
place names of both language areas, what they refer to and what the possible similarities and differences consist in (e.g. if colour terms are used more in their primary or secondary meaning and what colour terms are used in reference to specific landscape features). This attempt to compare different naming systems may also show how important and useful a common terminology framework for naming systems would be and how difficult (and in some respects rather impossible) it is to create a general one while taking into account the specifics of each system at the same time.

Quite obviously, the differences between these two language areas and naming systems stem from the origin of the languages, landscape types and the way how landscape features are perceived. In my opinion, these intrinsic differences do not hinder a comparative study, although they come up in seemingly small (yet important) details which have impact on how the material of both areas should be described and classified. Moreover, as Järventausta claims (2013: 108), the basis of any comparison is simply the observation that between the two languages there are features which can be considered the same or at least similar in some degree.

The account of differences relevant to the research project, i.e. a comparative study of colour terms in place names of two different language areas, includes the following: (1) differences in colour terms development because of (2) different language systems and their development, (3) different landscapes (and their history and perception) which all result in (4) a different classification of place names and (5) some cases of different terminology; moreover, (6) the ways of collecting place names in the past were different, and there are also (7) different language backgrounds, i.e. minority languages which have left their trace in local place names. These differences are closely intertwined, but for the sake of simplicity I have tried to break them down into individual items. Only the differences $1-5$ will be discussed here, and a particular attention will be paid to the issues related to classification and terminology.

\section{Colour terms and languages}

Berlin and Kay published their groundbreaking work Basic color terms: Their universality and evolution in 1969. Since then this theory has been reviewed several times (e.g. Kay \& McDaniel 1978; WCS 2009; Biggam 2012), but the basic concept has not changed. In a nutshell, Berlin and Kay claimed that in all languages ("universality") there are to be found and distinguished 2-11 basic colour terms and these tend to appear in a certain order ("evolution"). According to the number of these colour terms, any language can be ranked from stage 1 to stage 7 . Languages in stage 1 have only two colour terms (black and white, referring to light and dark shades), in stage 2 there are three colour terms (black, white, red), in stage 3 there are four 
(black, white, red, green or yellow), stage 4 has all the previously mentioned colour terms, stage 5 includes blue, stage 6 brown and stage 7 grey, and eventually orange, violet, pink (WCS 2009: 2-4).

With the number of basic colour terms, both Czech and Finnish classify for stage 7. However, there are differences in the number of the basic colour terms and also in the order these colour terms appeared in each language. In Finnish, there are eight basic colour terms: white, black, red, green, yellow, blue, brown, grey, but in Czech there are eleven (including orange, violet, pink). As for the order, in Finnish blue comes up already in stage 3, being an alternative to dark, cold chromatic colours (black was perceived as dark for achromatic colours), and also grey is thought to have appeared much earlier than in stage 7 as being related to old words for white. In Czech language, colour terms for grey and pink appear earlier and are better established in the language than brown which was originally used as one of the terms denoting red (Koski 1983: 259-261, 266; Štěpán 2004: 25-27).

The occurrence of basic colour terms in place names is related to the stage they appear in: the later they come up, the less frequent they tend to be (cf. Štěpán 2004: 27; Kiviniemi 1990: 155). The most frequent in both languages is the colour term for black (SPJČ) SPJČ IV. 2008: 14; Kiviniemi 1990: 152). ${ }^{2}$ However, the Finnish term for blue is in place names even more sporadic than those for gold, silver, brown, yellow and grey. This may actually correspond with the fact that it was perceived as "dark chromatic colour" (cf. Koski 1983: 260-261) and substituted by black (Kiviniemi 1990: 155).

\section{Language system and place name formation}

As for the differences in language systems, the fact that they belong to different language groups and families is most apparent in word formation processes. In Czech, as well as in other Slavic languages, derivation is the most frequent one (Čechová 2000: 93), whereas in Finnish it is compounding (Koivisto 2013: 51-52). Naturally, this applies not only to common nouns but also to place names. ${ }^{3}$ Especially in the case of Finnish place names this means that a great many of them are transparent and we can get at least a rough idea of what they might be referring to. It is thus not difficult to understand that the name Valkealampi ('White/Pool'; Kajaani/Lahnasjärvi, NA) refers to a pool,

2 In the area of Bohemia (Čechy) there are 1,111 place names containing černý (Czech adjective form of black, SPJČ) and 563 names containing bilý (Czech adjective form of white, SPJČ IV. 2008: 14). In the areas of Moravia and Silesia there have been documented 456 place names containing černý and 257 containing billý (SPJMS). This has also been observed in Finnish place names (Kiviniemi 1990: 152) and in Scandinavian languages (Huldén 1989: 169-172).

3 Štěpán (2016: 23) points out that the number of underived place names in the area of Bohemia makes up circa 40 percent. 
and the nearby name Valkealammensuo ('White/Pool/genitive// Swamp') to a swamp somewhere near this pool. The Czech place name $U$ Bílé vody ('At White Water'; Neveklov/Lešany, SPJ), on the other hand, does not give much clue that it is (was) referring to a forest. ${ }^{4}$

The differences stemming from two language types manifest themselves not only on the level of name formation but also on the level of defining the naming processes (cf. Ainiala et al. 2012: 75-80; Olivová-Nezbedová 1995a: 27-28). One of the approaches to Finnish place names is actually the syntacticsemantic analysis where the interpretation of the name is closely related to its structure (Ainiala et al. 2012: 53, 71-72). A similar approach to the structure of non-settlement place names has been introduced also in Czech onomastics by Jana Pleskalová (1992). Based on the material of Moravian and Silesian toponymy, she provides a classification in which the formal part and the naming process are related and help explain each other. ${ }^{5}$ In the case of Bohemian non-settlement names, Olivová-Nezbedová (1995b: 52) states that place names can originate either from common nouns or proper nouns and she analyses those based on other proper nouns from the lexical perspective of word formation. Just recently Pavel Štěpán (2016) has published his analysis of the structure of Czech non-settlement place names in Bohemia, dealing with derivation and paying particular attention to the functions of prefixes and suffixes in forming lexical units of place names.

In Finnish, the tendency to compounding is very strong. A compound place name (e.g. Valkealampi, see above) can become a root name for another compound name (e.g. Valkealammensuo), coming up as its specifying part. The whole new name is defined as an annexe (i.e. formed by attaching another element to an already existing place name) and considered a type of direct naming (Ainiala et al. 2012: 75-76). There is no exact equivalent in Czech toponymy to this. However, the indirect name (as for direct and indirect naming, see part 6 on terminology) can be perceived as a close parallel, especially when prepositions are applied in Czech place names. Prepositions as part of Czech place names are very frequent and they may come up both in direct or indirect naming. The occurrence of prepositional place names is the highest in the case of names denoting pieces of land, predominantly fields and pastures (Olivová-Nezbedová 1995a: 27).

In Czech toponomastics, seen from a purely formal perspective, there are distinguished one-word place names (the preposition is not counted as a word):

4 The location of individual examples is given as following: municipality/village (for Finnish place names) and district/village (for Czech place names). Both the municipality (in Finnish pitäjä 'parish') and the district (in Czech soudni okres 'judicial district') reflect the historical situation when the collecting of place names started.

5 Pleskalová's classification of "the structural model" is similar to "the word formation model” introduced by Rudolf Šrámek $(1972,1976)$, with the exception that Šrámek focused on settlement place names. 
e.g. Běla (a forest, Libochovice/Ředhošt', SPJ) or Na Bělí ('On Bělí' i.e. 'on a white place', a tract of land, Smíchov/Stodůlky, SPJ); and multiple-word place names: e.g. Přední bilý ('The front white [one]', a field, Nymburk/Loučeň Patřín, SPJ), U bilýho křže ('At the white cross', a field, Litoměřice/ Podsedice, SPJ) (Olivová-Nezbedová 1995a: 27-28). Actually, Czech nonsettlement place names tend to come up much more frequently in the multipleword form than settlement names do (Štěpán 2016: 22).

Analysing the differences in structure and formation of Finnish and Czech non-settlement place names is not the primary goal of my research, and it truly would be comparing the incomparable. Nonetheless, they should be paid attention to when examining the naming processes and motivations.

\section{Landscape types}

The differences of landscape types do not need that much of commenting as they are quite obvious. ${ }^{6}$ Nevertheless, the following three things should be pointed out.

Firstly, the frequency of place names corresponds with the landscape. In Bohemia, the most frequent ones are those of pieces of land (pozemková jména, 'agrarian names'), i.e. fields, pastures and forests (Olivová-Nezbedová 1995a: 27-28). In Finland, the most frequent ones are topographic names (maastonimet, 'terrain names'), i.e. names of terrain features, marshes and forests (Suomalainen paikannimikirja 2007: 11; Ainiala et al. 2008: 90-91).

Secondly, the prevailing features in the landscape also seem to come up as the naming motivation. The preliminary case study on names of forests and marshes containing the colour term white in both language areas shows that the naming motivation of the Czech place names came most frequently from the colour of soil (which is usually of a worse quality) and from the colour of plants or trees in the location. In Finnish place names, this colour term was in most cases passed on with the root name which originally referred to a water body or a watercourse (and to its good quality). The second most often recorded motivation is based on the colour of plants, such as trees, grass or lichen.

Thirdly, and most importantly, the way of how the landscape is perceived forms the classification system of place names in both language areas.

6 For those not familiar with Czech and/or Finnish types of landscape: The area the Czech Republic, despite being small in size, is quite varied as for landscape types, including lowlands, flatlands, undulating hills and mountains. Because of the landscape and also due to its geographical position in Central Europe, it is highly suitable for farming and most of the farming land actually consists of fields. Compared to the Czech Republic, Finland is vast but far less varied, the landscape being rather flat, covered in woods, different types of swamps, with great many types of water bodies and watercourses, and also seashores. 


\section{Place name classification}

The major difference in Finnish and Czech place name classifications consists in their basic division which is presented in Table 1. In both systems there are two main categories, but their perspective is different. Finnish place names are classified according to the presence (or absence) of human activity. The two categories are luontonimet 'nature names' and kulttuurinimet 'culture names'. On the other hand, the Czech classification is based on whether the names refer to settlements or not. The two categories are mistni jména or oikonyma 'settlement names' and pomístní jména or anoikonyma 'nonsettlement names'. The differences in categorisations influence how the subcategories of place names are ranked.

Table 1: Place names and their classification in Finnish and Czech (based on Ainiala et al. 2008: 27, 90; Ainiala et al. 2012: 26; Svoboda et al. 1973: 60-69; Olivová-Nezbedová 1995a: 15-16).

\begin{tabular}{|c|c|c|c|}
\hline \multicolumn{2}{|c|}{ FINNISH } & \multicolumn{2}{|c|}{ CZECH } \\
\hline A) luontonimet & A) nature names & A) non-settlement names & $\begin{array}{l}\text { A) pomístní jména } \\
\text { /anoikonyma }\end{array}$ \\
\hline 1. maastonimet & 1. topographic names & 1. terrain names & 1. oronyma \\
\hline \multirow[t]{3}{*}{ 2. vesistönimet } & 2. water names & 2. water names & 2. hydronyma \\
\hline & & $\begin{array}{l}\text { (3. non-settlement objects) } \\
\text { 3.1 names of roads, } \\
\text { bridges... } \\
\text { 3.2. names of individual } \\
\text { natural object and man- } \\
\text { made non-settlement } \\
\text { objects }\end{array}$ & $\begin{array}{l}3.1 \text { hodonyma } \\
3.2 \text { jména neživých } \\
\text { přírodních objektů a jevů } \\
\text { a člověkem vytvořených } \\
\text { objektů, která nejsou } \\
\text { určena k obývání }\end{array}$ \\
\hline & & 4. agrarian names & 4. pozemková jména \\
\hline & & B) settlement names & $\begin{array}{l}\text { B) místní jména/ } \\
\text { oikonyma }\end{array}$ \\
\hline $\begin{array}{l}\text { 3. artefaktinnimet } \\
3.1 \text { liikenteen nimet } \\
3.2 \text { rakennelmien } \\
\text { nimet }\end{array}$ & $\begin{array}{l}\text { 3. man-made objects } \\
\text { 3.1 transport names } \\
\text { 3.2 names of } \\
\text { structures }\end{array}$ & & \\
\hline 4. viljelysnimet & 4. agrarian names & & \\
\hline 5. asutusnimet & 5. settlement names & 5. settlement names & 5. místní jména \\
\hline
\end{tabular}

In Finnish, the nature names (names of places devoid of human activity) include the subcategories of topographic names and water names. The other three subcategories, artefaktinnimet 'names of man-made objects', viljelysnimet 'agrarian names', and asutusnimet 'settlement names' belong to 
culture names. In Czech classification system, settlement names make up their own category, whereas the category of non-settlement names includes all the other subcategories: terrain names, water names, names of roads, names of individual non-settlement objects, and agrarian names. Interestingly enough, in Finnish classification the subcategory of artefaktinnimet ('man-made objects', in Table 1, point 3.) includes both roads and non-settlement structures which are also presented as two different groups: liikenteen nimet (3.1 'traffic names', i.e. names of roads, paths, bridges), and rakennelmien nimet (3.2 'structure names', i.e. barns, hay shelters, etc.). These two pose a certain equivalent to the two subcategories in Czech classification system which are always presented as two separated ones: the first one includes names of roads (3.1 hodonyma) and the second one (3.2), which does not have a specific name yet, includes names of all other non-settlement objects in the landscape, including also the natural ones, e.g. boulders (Ainiala et al. 2008: 27, 90; Ainiala et al. 2012: 26; Svoboda et al. 1973: 60-69; Olivová-Nezbedová 1995a: 15-16).

Table 2: Classification of place names in Finnish and Czech according to the landscape features or objects they are referring to (based on Ainiala et al. 2008: 90-91; Ainiala et al. 2012: 26, 66; Olivová-Nezbedová 1995a: 15; Svoboda et al. 1973: 60-69).

\begin{tabular}{|c|l|l|}
\hline & FINNISH & CZECH \\
\hline $\begin{array}{c}\text { 1. (FIN/CZ) } \\
\text { topographic/terrain names }\end{array}$ & $\begin{array}{l}\text { mountains, valleys, hills, } \\
\text { knolls, boulders, rocks, } \\
\text { forests, bogs, marshes... }\end{array}$ & $\begin{array}{l}\text { mountains, valleys, hills, } \\
\text { knolls, islands, capes... }\end{array}$ \\
\hline $\begin{array}{c}\text { 2. (FIN/CZ) } \\
\text { water names }\end{array}$ & $\begin{array}{l}\text { watercourses/water } \\
\text { bodies, islands, capes... }\end{array}$ & $\begin{array}{l}\text { watercourses/water bodies, } \\
\text { bogs, marshes... }\end{array}$ \\
\hline $\begin{array}{c}\text { 3. (FIN/CZ) } \\
\text { 3.1 (FIN/CZ) names of roads }\end{array}$ & $\begin{array}{l}\text { roads, paths, bridges, } \\
\text { duckboards... }\end{array}$ & roads, paths, bridges... \\
\hline $\begin{array}{c}\text { 3.2 (FIN) names of structures } \\
\text { (CZ) non-settlement objects }\end{array}$ & hay shelters, barns... & $\begin{array}{l}\text { boulders, rocks... } \\
\text { quarries, hay shelters, barns, } \\
\text { crosses, chapels, } \\
\text { cemeteries... }\end{array}$ \\
\hline $\begin{array}{c}\text { 4. (FIN/CZ) agrarian names } \\
\text { finade) }\end{array}$ & fields, meadows, pastures & $\begin{array}{l}\text { fields, meadows, pastures, } \\
\text { forests (non/cultivated } \\
\text { pieces of land) }\end{array}$ \\
\hline 5. (FIN/CZ) settlement names & $\begin{array}{l}\text { municipalities, towns, } \\
\text { villages, their parts, } \\
\text { (groups of) houses (farms, } \\
\text { cottages)... }\end{array}$ & $\begin{array}{l}\text { towns, villages, their parts, } \\
\text { groups of houses, individual } \\
\text { buildings (pubs, farms)... }\end{array}$ \\
\hline
\end{tabular}

When analysing the material which includes place names whose classification may differ in respect to the language, it would seem logical to use only the subcategories which are almost equivalent. However, it would not 
be of much help because also individual landscape features are perceived and classified differently. As shown in Table 2, the classifications differ especially in ranking some of the most common landscape features. Land areas surrounded by water, for example islands or capes, are classified as water names in Finnish but as terrain names in Czech since here they refer to vertical features of Earth's surface. Forests are ranked as topographic names in Finnish but as agrarian names in Czech. Bogs or marshes are classified as topographic names in Finnish, whereas in Czech they belong to water names.

The names in subcategories 1 to 5 can be also described as microtoponyms, i.e. names used by a small group of people (Ainiala et al. 2012: $21,66)$. In Czech terminology, the term mikrotoponymum originally referred to the category of non-settlement names (Pleskalová 2017). Since most of Finnish and Czech place names available for the research come from rural areas and were (or still are) known only to the locals, the term microtoponym could be applied to both of them.

\section{Terminology}

When describing the classification systems in both languages, it is hard not to notice the terms which are used to denote the individual (sub)categories. In Finnish, these terms are Finnish and clear and understandable for those speaking Finnish. Czech toponomastics prefers terms based on Greek. For example, the term hydronyma, singular form hydronymum, tends to be used more often than jména vod 'water names'. One reason for that is probably the language economy, the other one the linguistic tradition.

The fact that the subcategories of place names in Czech and Finnish classification system may have a different content has just been mentioned. Therefore, in the situation where two classification systems are almost but not quite the same to provide exact equivalents, the most viable solution would be to create a classification that would reflect the nature of the research material. In this case it means to use the referents (individual landscape features and non-settlement objects which are perceived and described in the same way in both languages) without any further categorisation. In other words, instead of referring to a category, for example water names, specific items should be used, e.g. streams, lakes, pools, etc.

Another terminology-related issue is the naming process. In Czech toponomastics, non-settlement place names are characterised either according to their form, or from the perspective of naming (see Section 3 on place name formation). The name is direct (primary) when referring to the place or when based on a specific quality of the place, or indirect (secondary) when stating the position of the place in relation to another place or to its feature. This means that the name of the place in question can originate from the name of another place 
or object, usually the one in the immediate vicinity. An example of this is U Bilé vody (already mentioned in Section 3), the name of the forest being based on the clear little stream running there ${ }^{7}$ (Olivová-Nezbedová 1995a: 27-28). ${ }^{8}$

On the other hand, Finnish toponomastics distinguishes several means of name formation (Ainiala et al. 2012: 75-80). The first one is direct naming, which means that the name provides direct information about its referent. This is similar as in Czech, however, in Finnish the direct naming also includes the annexe names, which would be classified as indirect in Czech. The second type is indirect naming which in Finnish can result in metaphoric, metonymic, variation (based on phonetic or semantic change), or contrastive names. Metaphoric names are "founded on paralleled associations between a place and a concept" (ibid.: 77), e.g. Valkeaneva ('White swamp', a treeless swamp, Kaustinen/Kaustin kylä - Metsäkylä, NA) as it looks white because of the plant called hare's-tail cottongrass growing there. ${ }^{9}$ The metonymic names "are based on a relational association", which means that they are based either on a common noun or on another name, usually that of an adjacent place (ibid.: 78). For example, Valkeajärvi (Korpilahti/Valkeajärvi, NA) is the name of a lake but also of a farm built on the shore of this lake. The naming process is called metonymic transference and results in two names, the same in their form but referring to two different places. The last group of name formation is analogical name giving, which means that the name is "given according to existing nomenclature" (ibid.: 79), e.g. Valkiasuo and Mustasuo ('White bog' and 'Black bog', bogs, Kiiminki/Kiiminginkylä, NA) being situated close to each other. ${ }^{10}$

The classification of naming processes may differ not only between two languages but also within the very same one. As another classification of naming processes in Czech non-settlement place names, Pleskalová (1992: 16) presents seven types, 1) toponymisation, 2) metaphoric or metonymic relation of the place to another place, 3) derivation, 4) compounding, 5) forming twoor multiple-word names, 6) forming prepositional names, and 7) loaning toponyms and appellatives from foreign languages. Interestingly, Šmilauer

7 According to the informant: "potůček čisté bílé vody vytéká” (Neveklov/Lešany, SPJ) [a tiny stream of white clear water starting there].

8 Interestingly, even within Czech onomastics opinions on direct and indirect names differ. According to Šrámek, direct names are those in which the landscape feature or object is directly expressed, whereas indirect names are not only those expressing the position to another landscape feature or object but also those expressing a quality (Šrámek 1999: 16-17).

9 "Se on nīnko valakonen. Nimen arvellaan johtuvan nevalla kasvavasta 'Mustapää' nimisestä kasvista, joka tulee valkoiseksi." (Informant) [It's kind of whitish. The name is supposed to have originated from the plant called hare's-tail cottongrass which turns white.] The Finnish equivalent of 'hare's-tail cottongrass' is "musta/pää” ('black/head') or "tuppas/villa" ('tussock/wool'), cf. https://en.wikipedia.org/wiki/Eriophorum_vaginatum and https://fi.wikipedia.org/wiki/Tupasvilla.

10 In my opinion, this case can also be classified as a variation or a contrastive name. 
(1963: 159-167) lists metonymy under the "changes in the meaning of the name", depending whether the meaning is extended or narrowed in the same place or object and whether this happens in a different object of the same type, or a different object but situated in the vicinity. There is no term for metonymic transference in Czech onomastics, but Šrámek (2003) presents the issue of transonymisation as a form of a naming process, which could be considered an approximate equivalent.

\section{Conclusion}

Having discussed the differences and the possible issues they might bring about, it is evident that the focus of analysis must be on those features which in both languages are at least in some degree similar and therefore comparable. In the research of colour terms in place names, which can be considered both universal and present in each language, the similarity is to be found in the semantic analogy which is present per se both in colour terms and types of landscape. Although the development of the colour terms in each language slightly differs and the form of the name differs depending on the word formation processes of the given language, it is the occurrence and naming motivation what can be compared. The types of landscape are categorised differently, but this can be dealt with by referring solely to the individual landscape features, or even creating a specific classification based on the research material. In the same way, it is necessary to apply terminology with respect to the research material in the first place, to consider the use of other terms and to try to apply those which could reflect the language situation of each language, and most of all would be easy to use and give a clear and exact account of the research results.

\section{References}

Ainiala, Terhi \& Saarelma, Minna \& Sjöblom, Paula. 2008. Nimistöntutkimuksen perusteet [Introduction to onomastics]. Helsinki: SKS.

Ainiala, Terhi \& Saarelma, Minna \& Sjöblom, Paula. 2012. Names in focus: An introduction to Finnish onomastics. Helsinki: SKS. (https://oa.finlit.fi/ site/books/10.21435/sflin.17/) (Accessed 2020-03-06.)

Biggam, Carole P. 2012. The semantics of colour. A historical approach. Cambridge: Cambridge University Press.

Čechová, Marie. 2000. Čeština - ̌reč a jazyk [Czech - speech and language]. Praha: ISV.

Huldén, Lars. 1989. Svart och vitt i ortnamn [Black and white in place names]. In Peterson, Lena et al. (eds.), Studia Onomastica: festskrift till Thorsten Andersson den 23 februari 1989 [Studia Onomastica: Festschrift to 
Thorsten Andersson, 23rd February 1989], 166-174. Stockholm: Almqvist \& Wiksell.

Järventausta, Marja. 2013. Kontrastiivinen tutkimus vertailevan kielentutkimuksen kentässä [Contrastive research in comparative linguistics]. In Kolehmainen, Leena \& Miestamo, Matti \& Nordlund, Taru (eds.), Kielten vertailun metodiikka [The methodology of language comparison], 96-134. Helsinki: SKS.

Kay, Paul \& McDaniel, Chad K. 1978. The linguistic significance of the meanings of basic color terms. Language 54(3), 610-646.

Kiviniemi, Eero. 1990. Perustietoa paikannimistä [The basics of place name studies]. Helsinki: SKS.

Koivisto, Vesa. 2013. Suomen sanojen rakenne [The structure of Finnish words]. Helsinki: SKS.

Kolehmainen, Leena \& Miestamo, Matti \& Nordlund, Taru (eds). 2013. Kielten vertailun metodiikka [The methodology of language comparison]. Helsinki: SKS.

Koski, Mauno. 1983. Värien nimitykset suomessa ja lähisukukielissä [Colour terms in Finnish and Balto-Finnic languages]. Savonlinna: SKS.

$\mathrm{NA}=$ Nimiarkisto, Kotimaisten kielten keskus. [Names Archive, the Institute for the Languages of Finland]. (www.nimisampo.fi) (Accessed 2020-03-18.)

Olivová-Nezbedová, Libuše. 1995a. Pomístní jména v Čechách, jejich obecná charakteristika a jejich význam pro vědní obory [Non-settlement place names, their basic characteristics and importance for other scientific disciplines]. In Olivová-Nezbedová, Libuše (ed.), Pomistni jména $v$ Čechách, o čem vypovidaji jména polí, luk, lesů, hor, vod a strání [Nonsettlement place names in Bohemia, what the names of fields, meadows, forests, hills, waters and slopes speak about], 15-34. Praha: Academia.

Olivová-Nezbedová, Libuše. 1995b. Pomístní jména v Čechách vzniklá ze jmen vlastních odvozováním príponami [Bohemian non-settlement place names derived from personal names by derivational suffixes]. In Olivová-Nezbedová, Libuše (ed.), Pomistní jména v Čechách, o čem vypovídají jména polí, luk, lesü, hor, vod a strání [Non-settlement place names in Bohemia, what the names of fields, meadows, forests, hills, waters and slopes speak about], 52-80. Praha: Academia.

Pleskalová, Jana. 1992. Tvoření pomístnich jmen na Moravě a ve Slezsku [Nonsettlement place name formation in Moravia and Silesia]. Jinočany: H \& H.

Pleskalová, Jana. 2017. Pomístní jméno [Non-settlement place name]. In Karlík, Petr \& Nekula, Marek \& Pleskalová, Jana (eds.), CzechEncy - Nový encyklopedický slovnik češtiny [CzechEncy - The new encyclopaedic dictionary of the Czech language]. (https://www.czechency.org/ slovnik/POMÍSTNÍJMÉNO) (Accessed 2019-07-29.)

SPJ = Soupis pomistnich jmen (Čechy). [The general catalogue of nonsettlement place names in Bohemia]. Available at the Department of 
Onomastics, ÚJČ AV ČR, v.v.i., Prague. [Czech Language Institute, the Czech Academy of Sciences].

SPJČ = Slovník pomístních jmen v Čechách [The dictionary of non-settlement place names in Bohemia]. (https://spjc.ujc.cas.cz/) (Accessed 2019-07-25.)

SPJČ IV. = Matúšová, Jana \& Giger, Miriam \& Hamplová, Martina \& Malenínská, Jitka \& Procházková, Žaneta \& Steinerová, Jana \& Štěpán, Pavel. 2008. Slovník pomístních jmen v Čechách IV. (Bíg - Bož) [The dictionary of non-settlement place names in Bohemia IV. (Entries BígBož)]. Praha: Academia.

SPJMS = Slovnik pomistnich jmen na Moravě a ve Slezsku [The dictionary of non-settlement place names in Moravia and Silesia]. (https://spjms.ujc.cas.cz) (Accessed 2019-07-29.)

Suomalainen paikannimikirja [The dictionary of Finnish place names]. 2007. Kotimaisten kielten tutkimuskeskuksen julkaisuja 146. Helsinki: Karttakeskus.

Svoboda, Jan \& Šmilauer, Vladimír \& Olivová-Nezbedová, Libuše \& Oliva, Karel \& Witkowski, Teodolius. 1973. Základní soustava a terminologie slovanské onomastiky - Grundsystem und Terminologie der slawischen Onomastik [The basic terminology of Slavic onomastics]. Věnováno VII. mezinárodnímu sjezdu slavistů. - Gewidmet dem VII. internationalen Slawistenkongres. Zpravodaj Místopisné komise ČSAV, Vol. 14, No. 1.

Šmilauer, Vladimír. 1963. Úvod do toponomastiky [Introduction to toponomastics]. Praha: SPN.

Šrámek, Rudolf. 1972. Toponymické modely a toponymický systém [Toponymic models and toponymic system]. Slovo a slovesnost 33(4), 304-318. (http://sas.ujc.cas.cz/archiv.php?art=2197) (Accessed 2020-03-06.)

Šrámek, Rudolf. 1976. Slovotvorný model v české toponymii. [The wordforming model in Czech toponymy]. Slovo a slovesnost 37(2), 112-120. (http://sas.ujc.cas.cz/archiv.php?art=2371) (Accessed 2020-03-06.)

Šrámek, Rudolf. 1999. Úvod do obecné onomastiky [Introduction to onomastics]. Brno: Masarykova univerzita.

Šrámek, Rudolf. 2003. Transonymizace v propriální nominaci [Transonymisation in proprial nomination]. Folia onomastica Croatica 12-13, 499-508.

Štěpán, Pavel. 2004. Označení barev a jejich využití v toponymii Čech [Colour terms in the place names of Bohemia]. Praha: Univerzita Karlova, Filozofická fakulta. (Opera linguae bohemicae studentium 6.)

Štěpán, Pavel. 2016. Pomístníjména v Čechách z pohledu slovotvorného [Nonsettlement place names in the perspective of word formation]. Praha: Academia.

WCS $=$ Kay, Paul \& Berlin, Brent \& Maffi, Luisa \& Merrifield William, R. \& Cook, Richard. 2009. The world color survey. Stanford, California: CSLI Publications. 